UDC 336.025:338.242

JEL Classification: H2O, H71, F49, K34

http://doi.org/10.21272/mmi.2019.3-09

Inna Tiutiunyk,

Ph.D., Associate Professor, Sumy State University, Ukraine

Ihor Kobushko,

D.Sc., Professor, Sumy State University, Ukraine

Oleksandr Ivaniy,

Financial Analyst, Reporting and Investment Controlling, CAE Elektronik GmbH, Germany,

Certified Management Accountant, Institute of Management Accountants, NJ, USA

Anna Flaumer,

Kolping Academy, Germany

\title{
INNOVATIONS IN THE MANAGEMENT OF TAX GAPS IN THE ECONOMY: FOREIGN ECONOMIC COMPONENT
}

Abstract. Modern world transformational transitions occur under the influence of exogenous and endogenous factors, which, on the one hand, serve as stimulators of these processes, and, on the other hand, deepen imbalances in the country. One of the most influential factors for low- and middle-income countries is the economy shadowing. These are illegal financial transactions that hold back the investment and innovation development of the country, decreasing the pace of its social and economic development. Building an effective policy of neutralization and minimization of the influence of these factors is possible only if there is evidence-based research of all channels of income concealment and determination of the volume of each of them. Taking into account the low effectiveness of traditional approaches to managing the economy shadowing, the application of innovative evaluation methods based on the determination of the volume of tax gaps in the economy can serve as a ground for increasing the efficiency of the existing tools of public administration in this area. This article summarizes the arguments and counter-arguments within the framework of scientific discussion on the estimation of the volume of tax gaps in the economy in the context of the foreign economic activity of the country as one of the tools for minimizing tax liabilities. Systematizing these scientific developments on the definite problem has shown that among scientists there is no consensus on the role of tax gaps in the economy and their interrelation with foreign economic activity of the country, which significantly updates the need for further empirical research in this area, aimed at determining the volume of tax gaps by the export-import activity and their influence on indicators of economic development of the country. The research is based on the use of the modified Grubel-Lloyd formula (which allows determining the index of asynchronous export-import activity in the retrospective dynamics) and indicators of the level of asynchronous export-import activity by the partner countries. The study subject is the countries with the highest (Georgia), medium (Turkey, Cyprus, Solomon Islands) and the lowest (Japan, Austria, United States) levels of economy shadowing, which allows taking a more thorough and objective decision on the effect of asynchronous export and import activity on the volume of tax gaps in the economy, and its dependence on the level of shadowing in the country for 20132017. The paper presents the results of the empirical analysis of the volume gap of foreign economic activity on the example of Ukraine and its trading partners, which has shown that the highest index of asynchrony is peculiar to countries with average levels of shadowing - Cyprus, Solomon Islands, and the lowest - with the participation of countries with low level of shadowing. At the same time, it has been determined that one of the highest asynchronous indexes is obsenved with the participation of offshore countries. The study empirically confirms and theoretically proves that the foreign economic component plays a significant role in the processes of economic development of the country, and the number of hidden tax payments, due to these transactions, occupy about $1 \%$ of the country's GDP (gross domestic product). The results of the research may be useful for the relevant executive authorities in developing measures to prevent income shadowing in the context of export-import operations.

Keywords: economy shadowing, export operations, import operations, tax gap, asynchrony of foreign economic activity, innovative approaches of the economy unshadowing.

Cite as: Tiutiunyk, I., Kobushko, I., Ivaniy, O., \& Flaumer, A. (2019). Innovations in the Management of Tax Gaps in the Economy: Foreign Economic Component. Marketing and Management of Innovations, 3, 112-125. http://doi.org/10.21272/mmi.2019.3-09 
Introduction. Modern tendencies of economic development in the global and national terms are based on processes of large-scale transformation processes in relation to capital flow mechanisms, which change the structure and ways to place financial assets and cause the need to find new channels of their involvement. Strengthening European integration processes, levelling economic and political boundaries, and increasing the scope of export and import operations create prerequisites for expanding channels of shadow withdrawal abroad and increasing volumes of illegal operations in the country.

Modern tendencies of social and economic development of the majority of the world countries of the middle and low level of development, accompanied by low rates of GDP growth, a considerable level of off-the-books employment, unemployment, and inflationary processes in the country, indicate the need to find new mechanisms of management and tools for regulating the activities of economic actors, which will ensure, on the one hand, the balance of development of all components of the economic system, and on the other hand, will contribute to the growth of the economic security level of the state.

One of the reasons for the impossibility of fulfilling its functions by the state is the lack of tax income - one of the main sources of budget income. Tax policy is a key component of the financial policy of each country. Thus, according to the World Bank, despite the average annual growth of the world's value of this indicator in comparison with the crisis of $2009-2010$ (14.516\% in 2015 compared to $13.26 \%$ in 2009), during the last 2 years its value was somewhat reduced and now it is at the level of 2008. In general, the average level of tax revenues in the structure of GDP in the developed countries over the past decade was approximately 35\%. According to the results of 2016, Denmark had the highest value $33.74 \%$, Iceland $-38.52 \%$, Seychelles $-31.67 \%$, Sweden $-27.65 \%$. The United Arab Emirates has the lowest share of tax payments in the structure of GDP $-0.043 \%$, Iraq $-2.03 \%$, China $-9.157 \%$, Switzerland $-9.76 \%$ (World Bank, 2019).

In a context of increasing social and economic tensions in countries and the world as a whole, one of the reasons for the low level of tax revenues to the budget is the increase in the intensification of efforts of economic entities and households aimed at hiding the share of their income and shadowing. Every year there is an increase in the number and volume of illegal schemes for shadowing withdrawal of the funds abroad. Based on the results of the analysis carried out by the International Anti-Money Laundering Group, the annual amount of money laundering is 700 billion -2 trillion US dollars, which in average equals to $2-5 \%$ of world GDP and is said to cause a insignificant impact on the indicators of socio-economic development of the society (Report on money laundering methods typology in 20022003, 2013). According to calculations by Prof. F. Schneider (2015), the average level of the shadow economy in the EU in 2014 was $18.6 \%$ of GDP $(10.8 \%$ in France, $12.2 \%$ in Germany and $23.5 \%$ in Poland respectively).

The existence of the shadow economy has a range of economic and social consequences. One of them is the emergence of the phenomenon of tax gaps, the value of which today, according to estimates of international experts, is at $20 \%$ of tax revenues.

Literature Review. The essence of tax gaps, their relationship with the indicators of economic development of the country was actively studied by the representatives of the international economic community of many countries of the world.

Many authors investigated the essence of tax gaps in the economy. According to the American scientist Toder, the tax gap is the difference between the amount of taxpayers' tax liabilities in accordance with the law and the amount of taxes that were paid voluntarily and in a timely manner. In his opinion, the existence of the tax gap is due to the presence of three components: unregistered activities, underestimation of volumes and tax evasion (Toder, 2007).

Manusta and Warren defined the tax gap as the difference between the theoretical volume of tax liabilities and the amount of actual gross payments (McManus et al., 2006). 
Khwaja and lyer define tax gaps as the difference between the revenue potential (legal) and the actual revenue collected (Khwaja and lyer, 2014)

However, as a rule, in fact all authors agree that one of the main determinants of the emergence of tax gaps in the economy is the presence of the shadow economy, the main tool of which is tax evasion, whose share for some countries of the world is threatening (Fuest \& Riedel, 2010; Ebeke, Mansour, \& Rota-Graziosi, 2016; Bekoe, Danquah, \& Senahey, 2016).

Harremi (Harremi, 2014) stressed that the level of the tax burden in the country should take into account the degree of its economic development and the level of financial capacity, as otherwise, it would increase the aspirations of economic entities to avoid taxation and thus increase the burden on the tax administration.

The influence of this factor is described by Laffer curve, which shows that a low tax burden defines low shadow economy levels, while, increasing the tax burden above the optimal level specifies high amounts of the shadow economy, which, in its turn, reduces the tax revenues collection to the state budget (Schneider, Enste 2002). Another factor observed in terms of the impact in the shadow economy is the confidence level in government and good governance. Teobaldelli and Schneider (2013), Ipatov et. al (2018) confirmed that countries, where the fiscal regulation of the economy is carried out on a democratic basis, had a lower shadow economy.

Based on the examples of the foreign experience, Krumplyte (2008) demonstrates that countries with high tax burden (52-55 \%) are more competitive and have a small amount of the shadow economy (Sweden, Denmark, Finland). Countries with relatively low tax burden (up to 20\%) have the shadow economy in size of over $60 \%$ of GDP (Georgia, Mexico).

R. Murphy (Murphy, 2014), estimated the tax gap of Great Britain of $£ 122$ billion in 2014, besides, he stated that tax evasion was a major factor of the tax gap. He estimated the annual tax gap of 85 billion pounds sterling. Among the main determinants of tax avoidance, the author attributed: trading in shadow economy, untaxed proceeds of frauds and other crime, capital gains tax, inheritance tax, offshore tax abuse, criminal attacks on the tax system, failure to take care (taxpayers' errors or negligence), error (resulting from the action).

Harremi stated that tax evasion was $80-90 \%$ of the tax gaps in any country (Harremi, 2014).

Daniel Mitchell pointed out that the United States was characterized by low tax gaps, and the key to their reduction lied in the area of tax rates decrease and effective tax reforms (Mitchell, 2007).

Zdanowicz (2009), DeBoyrie et al. (2005), Pak et al. (2003) determined trade operations as the main tool for tax evasion, herewith, a significant role belonged to export-import operations.

Available numerous theoretical and empirical studies did not allow getting an unambiguous answer to this question. One of the reasons for this situation is the fact that the level of sensitivity of indicators of economic development of the country from the level of tax gaps in the economy is determined not only by the objective reasons of their interaction but also by the stability of economic development, the level of economic security, investment potential, the presence of economic or political crisis in the country. On the other hand, there is a great number of scientific works devoted to the study of the level and volume of single components of tax gaps, mainly for such taxes as VAT, corporate income tax. Besides, taking into account the difficulties encountered in assessing the individual components of the tax gap, it should be emphasized that any estimates of the tax gap are rather inaccurate and often have a subjective nature.

However, nowadays, there is no detailed study of the level of tax gaps in the context of certain types of economic activity (in particular, export-import operations), which will determine those that have the greatest impact on the level of economic development of the country.

The purpose of the paper is to study the role of export-import operations in the process of creating tax gaps in the economy and the development of an approach to assessing its level. 
Methodology and research methods. In the current conditions of the world economy, linked to the intensification of global economic processes, the growth of the divergence degree of economies and their level of openness, more and more economic entities are entering new foreign markets of goods and services.

Along with the economic causes of these actions within the framework of legal relations: the growth of sales of goods and services, the search for high-quality and cheaper raw materials, attracting investments, etc., one of the reasons is quite often the possibility of manipulating the value of exportimport operations in order to reduce the volume of their tax liabilities.

The most common schemes for minimizing the tax liability for export-import operations include the following:

- undervaluation of goods or raw materials (including by means of dumping prices);

- import of goods under the guise of transit, with the further receipt by importers of privileges for payment of customs and other types of taxes and fees;

- failure to record the imported goods supplied to the enterprises, and selling them as uncountable;

- concealment by employees of income received abroad and the fact of the settlement with them at the enterprise engaged in hiring;

- import of goods into the customs territory of Ukraine under the guise of humanitarian assistance;

- overloading a product from a foreign ship to the Ukrainian offshore, in order to obtain tax exemptions;

- replacement of the goods sold with the goods supplied without reflecting this fact in the report on sales volumes;

- artificial overrating/underevaluation of the customs value of goods in the course of import/export operations.

The implementation of all these shadow income schemes leads to a significant reduction in tax payments to the budget and, as a result, a deterioration in the country's economic development indicators.

In general, for today, payments for export-import operations play a significant role in the structure of tax payments to the budget. Despite the rather low worldwide average level of tax payments for exportimport operations (4\%), for some countries, its value is $20 \%$. Thus, we can conclude that manipulating the value of customs goods and services can significantly affect the volume of budget revenues. For countries such as Kazakhstan, Argentina, Belarus, Solomon Islands, the largest ratio in the structure of customs payments is the taxation of export operations, for the other countries analyzed - taxes and payments for import transactions (from 4 to $37 \%$ ).

In addition, a comparative analysis of the dynamics of changes in the volumes of export-import operations and shadowing of revenues, shown in Figure 2, has demonstrated the presence of feedback between them. Thus, the growth of volumes of export-import operations of goods and services for 20102015 for the overwhelming majority of the analyzed countries was accompanied by a simultaneous decrease in the level of shadowing. At the same time, the reduction of export-import operations took place in conditions of growth of shadow flows. Along with the objective reasons related to the change of the national currency rate, the economic crisis in some countries, the volumes of production and other indicators of economic development, we believe that it is the crisis processes in the country that catalyze the growth of shadow financial flows and reduce the officially declared volumes of foreign economic activity of economic entities.

Thus, the carried out analysis allows us to conclude on the important role of export-import operations in the economic life of the country. Taking into account the significant share of customs payments in the structure of state budget revenues, the enhanced control of the state by the completeness of the income 
I. Tiutiunyk., I. Kobushko, O. Ivaniy, A. Flaumer. Innovations in the Management of Tax Gaps in the Economy: Foreign Economic Component

declaration from these operations and the payment of customs payments becomes of importance. Unfortunately, the tendencies of changing the level of the shadow economy show significant disadvantages of the existing policy of shadowing the incomes of economic entities. The imperfection of the regulatory framework, a high level of corruption in the state, a large variety of schemes for illegal withdrawal of funds - all this only deepens these processes and exacerbates the economic crisis in the country, including through the tax gaps in the economy.

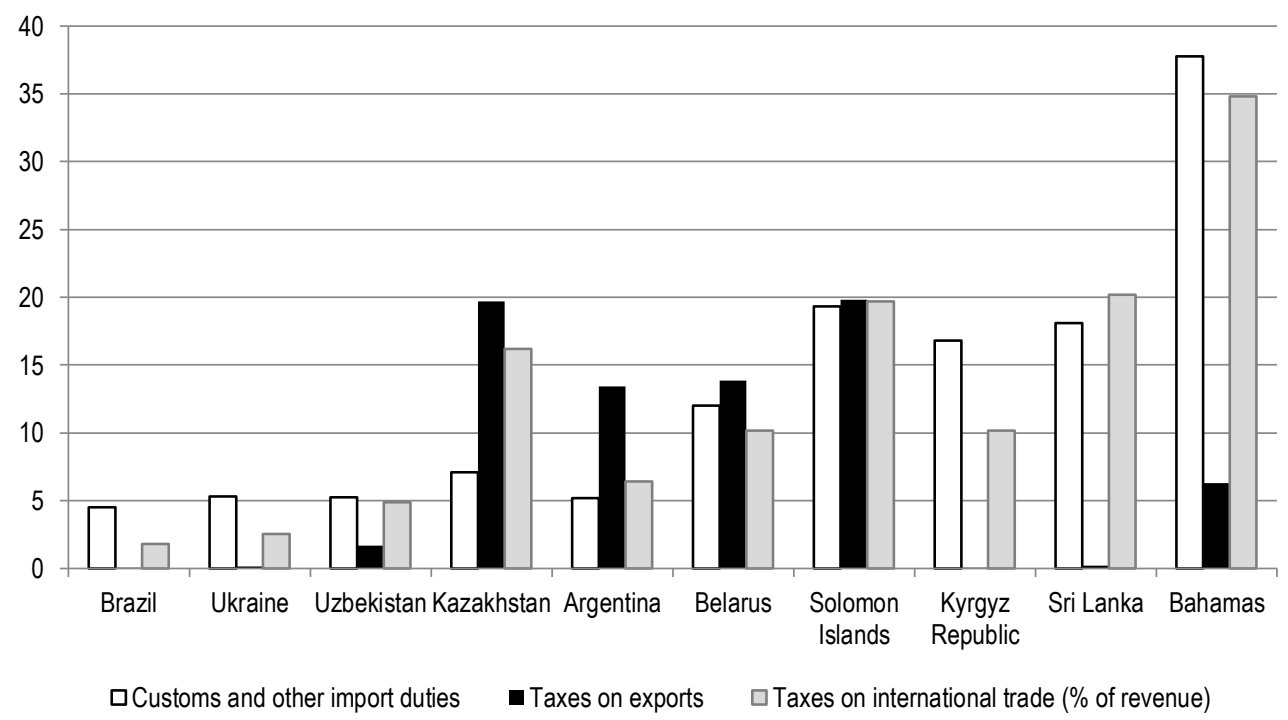

Figure 1. The share of customs payments in the structure of tax revenues of some countries of the world for $2010-2017, \%$

Sources: systematized by the authors on the basis of (World Bank, 2019)

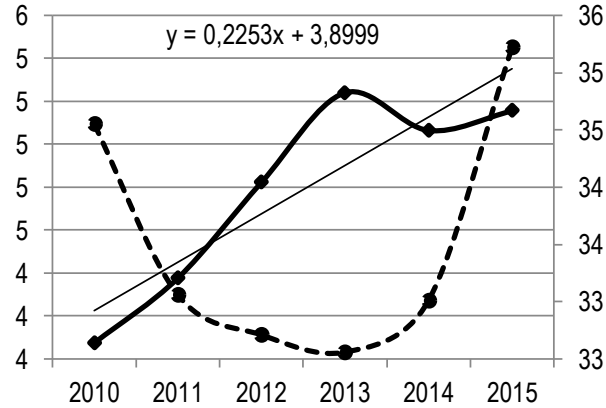

Customs and other import duties (\% of tax revenue)

- - - Level of shadow of capital

Brazil

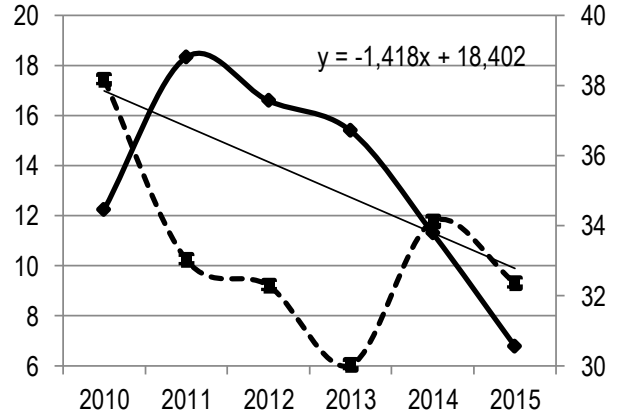

Customs and other import

Figure 2. Dynamics of changes in the volume of export-import operations and the level of the shadow economy in some countries of the world

Sources: systematized by the authors on the basis of (World Bank, 2019) 
Today, according to expert estimates, tax gaps as an indicator of budget losses, cause significant damage to the country's economic system. From the point of view of the taxpayer's behavior, this may involve intentional actions such as tax fraud, tax evasion, and aggressive tax planning, but the loss of income may also be due to oversight and insolvency. The analysis of the most common schemes for tax liability minimization through export-import operations is shown in Table 1.

Table 1. Tax evasion tools for export-import operations

\begin{tabular}{|c|c|c|}
\hline No. & Tool & Essence \\
\hline 1. & $\begin{array}{l}\text { Violation of } \\
\text { customs rules } \\
\text { and smuggling }\end{array}$ & $\begin{array}{l}\checkmark \text { concealment of foreign currency earnings abroad by reducing the } \\
\text { invoice value of goods or raw materials; } \\
\checkmark \text { concealment of import operations under the guise of the transit of } \\
\text { goods through the customs territory of the country, with the further receipt } \\
\text { by importers of privileges for payment of customs and other taxes and } \\
\text { duties (VAT, profit tax, excise tax, etc.); } \\
\checkmark \text { failure to record the imported goods supplied to the enterprises, and } \\
\text { selling them as uncountable; } \\
\checkmark \text { hiding employees of different specialties of the earned currency } \\
\text { abroad and the fact of the settlement with them at the enterprise engaged } \\
\text { in hiring; } \\
\checkmark \text { import of goods under the guise of humanitarian assistance; } \\
\checkmark \text { overload of the product from a foreign ship offshore, in order to } \\
\text { obtain tax exemptions; } \\
\checkmark \text { replacement of the goods sold with again supplied without reflecting } \\
\text { this fact in the report on sales volumes; }\end{array}$ \\
\hline 2. & $\begin{array}{l}\text { Manipulation } \\
\text { with the } \\
\text { export/import } \\
\text { value }\end{array}$ & $\begin{array}{l}\checkmark \text { artificial overrating/underevaluation of the customs value of goods in } \\
\text { the course of importlexport operations }\end{array}$ \\
\hline
\end{tabular}

Sources: compiled by the authors on the basis of (Vdovychenko, 2013; Dakhno, 2007)

A full and well-founded assessment of tax gaps will help to understand the extent of losses from failing to receive tax payments and will serve as a basis for identifying priority measures for improving the system of tax administration.

For example, the OECD (IFFR, 2018) developed the VAT return rate (VRR), which is an indicator reflecting the effect of income losses due to tax exemptions and tax cuts, fraud, tax evasion, and the policy gap (Fig. 1). Theoretically, the VRR measures the difference between actual VAT revenues and potentially possible, subject to the application of the base rate to all taxpayers and tax bases, without exception.

Thus, minimization of the policy gap should be considered as an indicator of additional income that the state could theoretically obtain, subject to full taxation of the total volume of goods and services.

There are two main approaches to assessing tax gaps:

1) The «top-down» method consists in a macroeconomic evaluation of tax gaps. This method is based on the calculation of the difference between the magnitude of potential tax revenues and actually received revenues. Estimates of potential revenues are usually based on statistical data. The main advantage of this method is that it does not require significant resources and time, and the results obtained are suitable for comparison retrospectively. 
2) At the same time, the disadvantage of this approach is that on its basis it is possible to estimate only those activities and branches of the economy that can be tracked in macroeconomic statistics, and the quality of the results obtained depends on the completeness and correctness of macroeconomic data. In addition, the disadvantage of this approach is that the input data are sufficiently aggregated and do not allow estimating the volume of tax gaps in a particular type of tax, a separate operation, etc.

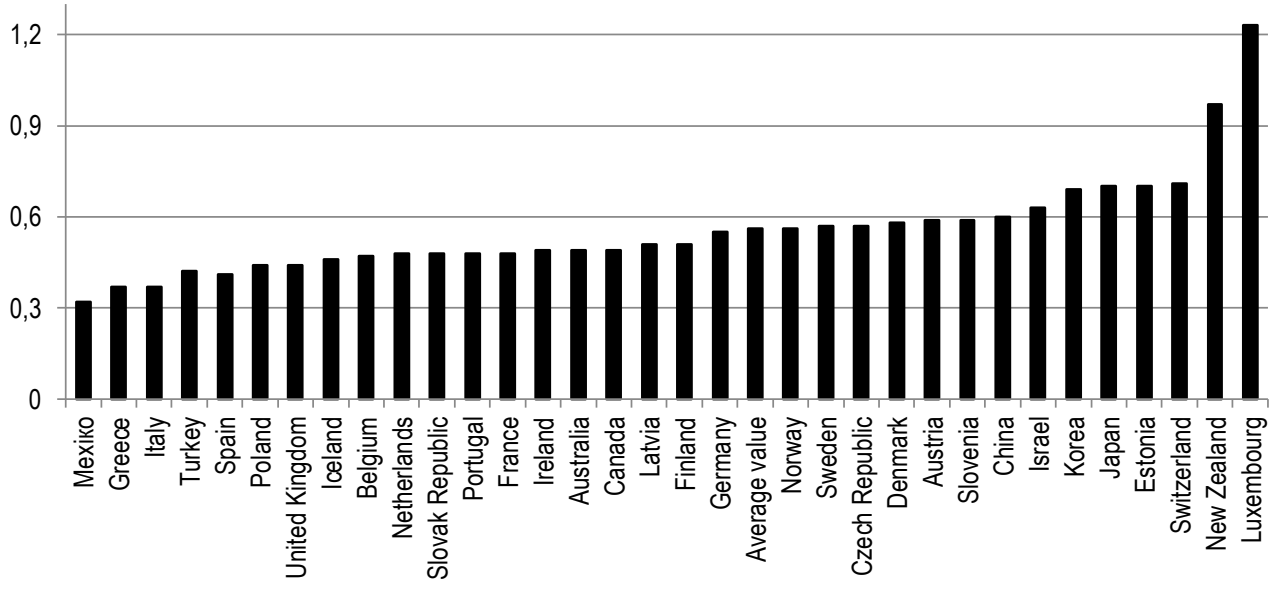

Figure 3. VAT income rate

Sources: compiled by the authors on the basis of (IFFR, 2018)

When choosing this group of methods, it is necessary to take into account the fact that the official data of macroeconomic statistics do not reflect the international aspects of evasion from payment of tax payments related to the withdrawal of funds from the offshore, the investment of assets abroad, etc. Estimates based on these approaches tend to have a time lag of 2 years and require regular review.

3) The «top-down» approach. The difference of this approach is the high level of detailing the calculations, which allows not only to determine the amount of tax gaps for certain types of taxes, operations, and activities but also to obtain information on the compliance of tax legislation by every single taxpayer. At the same time, the disadvantage of this approach is that it covers only specific sources of tax gaps - and does not provide a comprehensive picture of the total amount of tax gaps in the economy.

Since the source of the original data is commonly the reports of the tax administration; also, this approach does not provide the estimation of the deliberate and covert actions of economic entities aimed at reducing tax liabilities.

If a «top-down» estimation can give a general estimation of tax gaps and does not provide detailed information on what sectors or economic entities cause their existence, a «top-down» estimation may provide more detailed information that can be used by public tax administration authorities in the process of counteracting the shadowing of revenues.

However, according to the results obtained on the basis of these approaches, their calculations differ significantly from the results of estimations obtained by independent institutions - the World Bank, the International Monetary Fund, etc. As a rule, the declared indicators are much smaller, comparing with international ones, and indicate incomplete incorporation of all components of the economy shadowing. 
In turn, the method for assessing tax gaps provides an opportunity to more fully estimation of the level of administrative efficiency in the context of each separate tax type and identification of the most priority sectors of the economy, regions, areas of activity in terms of enhancing state control in the area of counteraction to shadowing.

The practice of estimating tax gaps is applied in a large number of countries, both with the high and medium level of development. In order to identify the features of calculating the tax gap for VAT and to take into account the best practices in implementing this approach in Ukraine, we will conduct a more detailed analysis of the procedures for assessing the tax gap in the context of some countries of the world.

One of the main drawbacks of existing evaluation methods is that actually all of them are based on existing data in the state, some of which are false since they are submitted by economic entities participants of shadow operations.

For this purpose, in our opinion, it would be reasonable to develop a methodological approach to assessing the tax gap of export-import operations, which would take into account the data of the exporting country and partner country. For example, quite often in the course of export operations in the exporting country, in order to avoid taxation, much fewer goods than those actually transported abroad are declared, while the partner country declares the true volume of imports.

Under these conditions, one can talk about the asynchrony of the foreign economic activity of the country. The question of asynchronous development was studied in scientific works mainly from two perspectives: as a characteristic of the degree of stability of the economic system and as a peculiar feature in most economic systems.

The analysis of the level of asynchronous export-import activity of the country consists in comparing the value of the export/import of the producing country and the cost of import/export of the partner country. An estimation of the influence of foreign economic activity on the Index of bilateral asynchronous export-import activity of the country $\left(\mathrm{IBS}_{\mathrm{i}, \mathrm{j}}\right)$ will be carried out using the modified Grubel Lloyd formula (1975):

$$
I B S_{i, j}=1-\frac{\sum_{k}\left|\exp _{i, j}^{k}-i m p_{j, i}^{k}\right|}{\sum_{k}\left(\exp p_{i, j}^{k}+i m p_{j, i}^{k}\right)}
$$

where $\exp ^{k_{i, j}}$ - value of the export of the product $k$ of the country of production I to the partner country $j ; i^{2} p_{j, i}$ value of the import of the product $k$ from the partner country $j$ to the country $i$.

The greater the value of this indicator is close to 1, the higher the synchronization rate is observed between the countries and, accordingly, the volume of shadow export-import operations is smaller.

The calculation of the asynchronous index will allow the identification of partner countries that are characterized by the highest level of risk related to the possible concealment of tax payments for a certain time horizon. Decision-making based on the results of one year is rather insignificant and subjective, since the imbalance of indicators may be temporary and objective.

Estimation of the level of asynchronous export-import activity of the above-mentioned countries for individual years using the following formulas:

$$
R_{a s h_{i m p}}=\frac{i m p_{i}}{\exp _{j}}, \quad R_{a s h}=\frac{e x p_{i}}{i m p_{i}}
$$

Assessing the level of asynchronous export activity, the excess of this coefficient 1 indicates the possible application of shadow tax minimization schemes, the main ones of which may be overestimated export of goods for the purpose of obtaining the unlawful receipt of VAT refunds from the budget, withdrawal of funds to the banking centers. At the same time, the substantial underestimation of the 
specified indicator for import operations reflects a deliberate underestimation of the number of tax payments.

The existence of the asynchronous phenomenon of foreign economic activity leads to the emergence of tax gaps in the economy caused by avoidance of taxation or receipt of funds from the budget with a purpose of reimbursement of the tax paid on these operations. The size and algorithm of calculating the tax gap for export-import operations will differ significantly depending on the peculiarities of the tax legislation of the country, the availability, size, and types of tax gaps for export-import operations.

The calculation of tax gaps for export-import operations was conducted on the example of Ukraine. Thus, according to the Tax Code and other laws and regulations of Ukraine, the implementation of export-import operations provides for the payment of the following payments:

- charge on imports $\left(I D_{i}\right)$ and exports $\left(E D_{j}\right)$;

- excise tax on imported excisable goods (products) to the customs territory of the country (ExcTaximp);

- VAT from imported works, services, and imported goods to the territory of Ukraine (VAT imp);

- the only fee that is collected at checkpoints across the state border of Ukraine $\left(C_{\text {att }}\right)$;

- fees for the execution of customs formalities by revenue and fees authorities outside the place of their location or outside of working hours established for them (SC).

Taking into account the aforementioned, the generalized formula for calculating the tax gap for these operations (on the example of Ukraine) will look like as follows:

$$
\mathrm{TG}_{\mathrm{it}}=\sum_{i=1}^{n} I D_{i} \cdot I_{\text {asimp }}+\sum_{j=1}^{m} E D_{j} \cdot I_{\text {asexp }}+\sum_{i=1}^{n} E x c T a x_{i m p_{i}} \cdot I_{\text {asimp }}+\sum_{i=1}^{n} V A T_{\text {imp }} \cdot I_{\text {asimp }}+C s t f \cdot I_{a s}+S C \cdot I_{\text {askg }}
$$

Results. In order to confirm the established hypothesis, we provide the results of calculating the level of asynchrony for some countries of the world, characterized by the highest (Georgia), medium (Turkey, Cyprus, Solomon Islands) and the lowest (Japan, Austria, United States) levels of shadowing economy. The results of the calculations are given in Table 2 .

Table 2. The results of the asynchronous index of export-import activity of some countries of the world for 2013-2017

\begin{tabular}{|c|c|c|c|c|c|c|c|c|c|c|c|c|}
\hline & \multicolumn{2}{|c|}{ Turkey } & \multicolumn{2}{|c|}{ Cyprus } & \multicolumn{2}{|c|}{$\begin{array}{c}\text { Solomon } \\
\text { Islands }\end{array}$} & \multicolumn{2}{|c|}{ Japan } & \multicolumn{2}{|c|}{ Austria } & \multicolumn{2}{|c|}{ United States } \\
\hline & 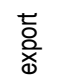 & 등 & $\begin{array}{l}\text { t } \\
\text { o } \\
\text { x }\end{array}$ & 등 & $\begin{array}{l}\text { 등 } \\
\text { ख }\end{array}$ & 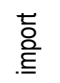 & $\begin{array}{l}\text { 등 } \\
\text { ख }\end{array}$ & 등 & $\begin{array}{l}\text { 등 } \\
\text { 잉 }\end{array}$ & 들 & $\begin{array}{l}\text { 등 } \\
\frac{0}{x}\end{array}$ & $\stackrel{\text { 늘 }}{\underline{\underline{g}}}$ \\
\hline Georgia & 0.94 & 0.92 & 0.19 & 0.20 & 0.00 & 0.00 & 0.61 & 0.99 & 0.57 & 0.98 & 0.74 & 0.63 \\
\hline Turkey & - & - & 0.14 & 0.09 & 0.71 & 0.17 & 0.76 & 0.82 & 0.69 & 0.96 & 0.13 & 0.94 \\
\hline Cyprus & - & - & - & - & 0.00 & 0.00 & 0.23 & 0.38 & 0.52 & 0.58 & 1.00 & 0.79 \\
\hline $\begin{array}{l}\text { Solomon } \\
\text { Islands }\end{array}$ & - & - & - & - & - & - & 0.67 & 0.76 & 0.00 & 0.00 & 0.98 & 0.98 \\
\hline Japan & - & - & - & - & - & - & - & - & 0.63 & 0.95 & 0.98 & 0.95 \\
\hline Austria & - & - & - & - & - & - & - & - & - & - & 0.94 & 0.80 \\
\hline
\end{tabular}

Sources: compiled by the authors on the basis of (World Bank, 2019)

As the calculations show, the highest index of asynchronous export-import activity is observed between countries with an average level of shadowing - Cyprus, Solomon Islands, the lowest - among countries with low level of shadowing. At the same time, it should be noted that a significant 
I. Tiutiunyk., I. Kobushko, O. Ivaniy, A. Flaumer. Innovations in the Management of Tax Gaps in the Economy: Foreign Economic Component

asynchronous index is observed with the participation of offshore countries, which are often characterized by preferential tax treatment.

As the results of calculations given in Table 3 show, the highest level of asynchronous export activity is typical for Solomon Islands - Austria (2168.0 - 2014, 724.5 - 2015, 1716.1-2017), Solomon Islands Turkey (186.8 in 2013), import activities - Solomon Islands - Georgia (0 in 2013-2016), Austria Solomon Islands (0 in 2013-2017).

Table 3. Estimation of the asynchronous level of export-import activity of some countries of the world for 2013-2017

\begin{tabular}{|c|c|c|c|c|c|c|c|c|c|c|c|c|c|c|c|}
\hline & & \multicolumn{2}{|c|}{ Georgia } & \multicolumn{2}{|c|}{ Turkey } & \multicolumn{2}{|c|}{ Cyprus } & \multicolumn{2}{|c|}{$\begin{array}{l}\text { Solomon } \\
\text { Islands }\end{array}$} & \multicolumn{2}{|c|}{ Japan } & \multicolumn{2}{|c|}{ Austria } & \multicolumn{2}{|c|}{ United States } \\
\hline & & $\begin{array}{l}\frac{1}{2} \\
\frac{2}{x}\end{array}$ & 흠 & $\begin{array}{l}\frac{t}{0} \\
\frac{2}{x}\end{array}$ & 끔 & $\begin{array}{l}\text { t } \\
\text { ơ } \\
\frac{0}{x}\end{array}$ & $\begin{array}{l}\text { ț} \\
\text { 를 }\end{array}$ & $\begin{array}{l}\text { to } \\
\text { o } \\
\text { x }\end{array}$ & $\begin{array}{l}\text { 늠 } \\
\text { 을 }\end{array}$ & $\begin{array}{l}t \\
\frac{0}{x} \\
\frac{0}{0}\end{array}$ & 늠 & $\begin{array}{l}t \\
\text { to } \\
\text { à } \\
0\end{array}$ & ťㅡㄹ & $\begin{array}{l}t \\
\text { to } \\
\text { à } \\
0\end{array}$ & 늠 \\
\hline \multirow{5}{*}{ 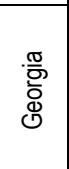 } & 2013 & - & - & 0.9 & 1.1 & 0.0 & 7.5 & 0.0 & 0.0 & 0.6 & 0.9 & 0.0 & 0.8 & 0.8 & 0.4 \\
\hline & 2014 & - & - & 1.0 & 1.2 & 1.7 & 4.9 & 0.0 & 1.0 & 0.3 & 1.0 & 0.8 & 1.0 & 0.5 & 0.5 \\
\hline & 2015 & - & - & 0.8 & 1.2 & 1.8 & 5.9 & 0.0 & 2.0 & 0.3 & 1.6 & 0.6 & 1.1 & 0.6 & 0.1 \\
\hline & 2016 & - & - & 0.8 & 1.1 & 1.5 & 4.0 & 0.0 & 3.0 & 0.4 & 1.1 & 0.2 & 1.0 & 0.7 & 0.7 \\
\hline & 2017 & - & - & 1.0 & 1.1 & 0.1 & 24.1 & 0.0 & 4.0 & 0.6 & 0.7 & 0.6 & 1.0 & 0.9 & 0.7 \\
\hline \multirow{5}{*}{ 离 } & 2013 & 0.9 & 1.1 & - & - & 182.0 & 101.8 & 0.0 & 0.0 & 0.7 & 1.5 & 0.7 & 1.1 & 84.6 & 1.0 \\
\hline & 2014 & 0.8 & 1.0 & - & - & 0.0 & 1.9 & 0.8 & 39.4 & 0.6 & 1.5 & 0.7 & 1.2 & 0.8 & 1.1 \\
\hline & 2015 & 0.8 & $\begin{array}{ll}1.3 \\
\end{array}$ & - & - & 0.0 & 0.1 & 2.5 & 3.8 & 0.5 & 1.5 & 0.6 & 1.1 & 0.1 & 1.2 \\
\hline & 2016 & 0.9 & 1.2 & - & - & 0.0 & 0.3 & 0.7 & 5.0 & 0.6 & 1.4 & 0.6 & 1.1 & 0.8 & 1.2 \\
\hline & 2017 & 0.9 & 1.0 & - & - & 10.4 & 15.3 & 3.1 & 0.0 & 0.7 & 1.4 & 0.1 & 1.0 & 0.9 & 1.2 \\
\hline \multirow{5}{*}{ 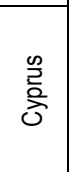 } & 2013 & 0.1 & 30.3 & 0.0 & 0.0 & - & - & 1.0 & 1.0 & 0.0 & 0.1 & 0.0 & 0.2 & 1.8 & 0.7 \\
\hline & 2014 & 0.2 & 0.6 & 0.5 & 54.7 & - & - & 1.0 & 1.0 & 0.6 & 0.2 & 0.1 & 0.5 & 1.0 & 0.6 \\
\hline & 2015 & 0.2 & 0.6 & 11.0 & 55.2 & - & - & 1.0 & 1.0 & 1.3 & 0.2 & 0.2 & 0.6 & 1.0 & 0.6 \\
\hline & 2016 & 0.2 & 0.7 & 3.9 & 44.0 & - & - & 0.0 & 1.0 & 1.1 & 0.4 & 0.3 & 1.1 & 1.0 & 0.7 \\
\hline & 2017 & 0.0 & 7.7 & 0.1 & 0.1 & 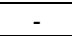 & 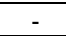 & 0.0 & 1.0 & 2.2 & 0.4 & 0.2 & 0.6 & 1.0 & 1.1 \\
\hline \multirow{5}{*}{ 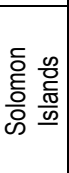 } & 2013 & 0.0 & 0.0 & 186.8 & 0.0 & 0.0 & 0.0 & - & - & 0.2 & 1.6 & 0.0 & 0.0 & 1.1 & 1.3 \\
\hline & 2014 & 1.0 & 0.0 & 0.0 & 1.3 & 0.0 & 0.0 & - & - & 0.4 & 1.4 & 2168.0 & 2465.8 & 1.2 & 1.0 \\
\hline & 2015 & 1.0 & 0.0 & 0.3 & 0.4 & 0.0 & 0.0 & - & - & 0.7 & 2.4 & 724.5 & 2403.1 & 0.2 & 0.9 \\
\hline & 2016 & 0.0 & 0.0 & 0.2 & 1.4 & 0.0 & 10.9 & - & - & 0.6 & 1.4 & 0.0 & 0.0 & 0.8 & 0.7 \\
\hline & 2017 & 1.0 & 1.0 & 0.0 & 0.3 & 0.0 & 12.5 & - & - & 0.4 & 1.5 & 1716.1 & 1821.9 & 1.0 & 0.9 \\
\hline \multirow{5}{*}{ 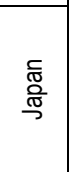 } & 2013 & 1.2 & 1.6 & 0.7 & 3.9 & 8.6 & 39.4 & 0.6 & 4.1 & - & - & 0.4 & 1.0 & 1.0 & 1.1 \\
\hline & 2014 & 1.0 & 3.0 & 0.7 & 4.5 & 6.5 & 1.8 & 0.7 & 2.4 & - & - & 0.5 & 1.1 & 1.0 & 1.1 \\
\hline & 2015 & 0.6 & 3.2 & 0.7 & 4.8 & 4.5 & 0.8 & 0.4 & 1.4 & - & - & 0.5 & 1.1 & 0.9 & 1.1 \\
\hline & 2016 & 0.9 & 2.5 & 07 & 4.8 & 2.8 & 0.9 & 0.7 & 1.6 & - & - & 0.5 & 1.2 & 1.0 & 1.1 \\
\hline & 2017 & 1.4 & 1.8 & 0.7 & 4.2 & 2.4 & 0.5 & 0.7 & 2.4 & - & - & 0.0 & 1.1 & 1.0 & 1.1 \\
\hline \multirow{5}{*}{ 乩 } & 2013 & 1.3 & 22.4 & 0.9 & 1.5 & 6.3 & 7.5 & 0.0 & 0.0 & 1.0 & 2.4 & - & - & 0.9 & 1.6 \\
\hline & 2014 & 1.0 & 1.3 & 0.9 & 1.5 & 2.2 & 2.9 & 0.0 & 0.0 & 0.9 & 2.5 & - & - & 0.9 & $\begin{array}{l}1.5 \\
\end{array}$ \\
\hline & 2015 & 0.9 & 1.8 & 1.0 & 1.6 & 1.8 & 2.3 & 0.0 & 0.0 & 0.9 & 2.0 & - & - & 0.8 & 1.4 \\
\hline & 2016 & 1.0 & 4.2 & 0.9 & 1.6 & 0.9 & 1.4 & 0.0 & 0.0 & 0.8 & 2.1 & - & - & 0.8 & $\begin{array}{l}1.5 \\
\end{array}$ \\
\hline & 2017 & 1.0 & 1.6 & 1.0 & 15.6 & 1.6 & 1.5 & 0.0 & 0.0 & 0.9 & 2.0 & - & - & 0.9 & 1.5 \\
\hline \multirow{5}{*}{ 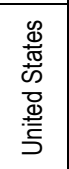 } & 2013 & 2.4 & 1.3 & 0.9 & 0.0 & 1.5 & 0.6 & 0.8 & 0.9 & 0.9 & 1.0 & 0.6 & 1.1 & - & - \\
\hline & 2014 & 27 & 2. & 1.0 & 1.2 & 1.6 & 1.0 & 1.0 & 0.8 & 0.9 & 1.1 & 0.7 & 1.1 & - & - \\
\hline & 2015 & 13.5 & 1.8 & 0.9 & 13.1 & 1.7 & 1.0 & 1.1 & 4.1 & 0.9 & 1.1 & 0.7 & 1.2 & - & - \\
\hline & 2016 & 1.5 & 1.4 & 0.8 & 1.3 & 1.3 & 1.0 & 1.5 & 1.2 & 0.9 & 1.0 & 0.7 & 1.2 & - & - \\
\hline & 2017 & 1.4 & 1.1 & 102.0 & 1.1 & 0.9 & 1.0 & 1.1 & 1.0 & 0.9 & 1.0 & 0.7 & 1.1 & - & - \\
\hline
\end{tabular}

Sources: compiled by the authors on the basis of (World Bank, 2019) 
I. Tiutiunyk., I. Kobushko, O. Ivaniy, A. Flaumer. Innovations in the Management of Tax Gaps in the Economy: Foreign Economic Component

Table 4. Estimation of asynchronous index of export-import activity of Ukraine and partner countries for 2013-2017

\begin{tabular}{|c|c|c|c|c|c|c|}
\hline $\begin{array}{l}\text { Partner } \\
\text { country }\end{array}$ & $\begin{array}{l}\text { Asynchronous export } \\
\text { index for 2013-2017 }\end{array}$ & $\begin{array}{c}\text { Asynchronous } \\
\text { import index for } \\
2013-2017\end{array}$ & $\begin{array}{c}\text { Asynchronous } \\
\text { export level }\end{array}$ & $\begin{array}{l}\text { Asynchronous } \\
\text { import level }\end{array}$ & TG & $\begin{array}{l}\text { Share } \\
\text { of GDP }\end{array}$ \\
\hline Austria & 0.78 & 0.99 & 1.33 & 1.08 & 0.02 & $0.0007 \%$ \\
\hline Azerbaijan & 0.12 & 0.79 & 7.36 & 1.01 & 0.01 & $0.0003 \%$ \\
\hline Bulgaria & 0.90 & 0.90 & 0.92 & 1.10 & - & - \\
\hline Cyprus & 0.34 & 0.39 & 1.94 & 3.06 & 0.00 & $0.0001 \%$ \\
\hline $\begin{array}{l}\text { Czech } \\
\text { Republic }\end{array}$ & 0.82 & 0.91 & 0.63 & 5.54 & - & -- \\
\hline France & 0.88 & 0.80 & 0.73 & 1.91 & - & - \\
\hline Georgia & 0.95 & 0.97 & 0.94 & 0.90 & 2.01 & $0.0675 \%$ \\
\hline Germany & 0.84 & 1.00 & 0.71 & 1.01 & - & - \\
\hline Greece & 0.82 & 0.82 & 0.68 & 1.47 & - & - \\
\hline Hungary & 0.98 & 0.98 & 1.31 & 0.76 & 3.75 & $0.1259 \%$ \\
\hline Italy & 0.81 & 0.80 & 1.42 & 0.70 & 4.90 & $0.1641 \%$ \\
\hline Lithuania & 0.56 & 0.57 & 0.52 & 1.91 & - & - \\
\hline Poland & 0.87 & 0.87 & 0.82 & 1.22 & - & - \\
\hline Portugal & 0.34 & 0.34 & 4.51 & 0.22 & 0.45 & $0,0151 \%$ \\
\hline $\begin{array}{l}\text { Slovak } \\
\text { Republic }\end{array}$ & 0.88 & 0.88 & 1.08 & 0.92 & 0.49 & $0.0164 \%$ \\
\hline Slovenia & 0.15 & 0.14 & 0.12 & 8.19 & - & - \\
\hline Spain & 0.73 & 0.73 & 2.01 & 0.50 & 1.94 & $0.0650 \%$ \\
\hline Sweden & 0.29 & 0.23 & 0.17 & 5.88 & - & - \\
\hline Switzerland & 0.37 & 0.25 & 0.11 & 9.28 & - & - \\
\hline Turkey & 0.59 & 0.58 & 1.87 & 0.54 & 3.29 & $0.1103 \%$ \\
\hline United States & 0.48 & 0.47 & 0.25 & 3.96 & - & - \\
\hline \multicolumn{5}{|l|}{ Total } & 19.71 & $0.6608 \%$ \\
\hline
\end{tabular}

Sources: compiled by the authors on the basis of (World Bank, 2019)

Thus, for the period of 2013-2017, the index of asynchronous export activity for the vast majority of trading partner countries of Ukraine is above the average ( 0.8 and above), which may be due to deliberate actions of taxpayers to conceal their own tax liabilities, and technical inaccuracies or other reasons not related to shadow operations. At the same time, for the United States, Switzerland, Sweden, Slovenia, Portugal, Azerbaijan, Cyprus, the value of this indicator is critically low (0.12-0.4) and is evidence of the use of income concealment tools.

A similar situation is observed with the index of asynchronous import activity. Despite the fact that its value is somewhat higher compared to the same indicator of export activity, the following countries have a critically low level: Portugal (0.34), Slovenia (0.14), Sweden (0.23), Switzerland (0.25).

At the same time, the calculation of asynchronous levels of export and import operations in 2017 allowed the countries to identify the illegal tax schemes of income shadowing and the level of the tax gap for these operations for Ukraine. As a result of the calculations, the amount of the tax gap was estimated at 19.71 billion UAH, which is $0.66 \%$ of the country's GDP in 2017 .

Conclusions. In the current economic conditions, followed by transformational changes in society and big-bang reforms in the economic, political and social spheres, the availability of sufficient amount of budget funds serves as a ground and a prerequisite for the successful implementation of these tasks.

However, as the analysis shows, the presence of economic and political changes in the country is followed by an increase in the volume of shadow financial flows and the diversity of the corrupt schemes used. 
However, practical experience shows that existing tools for estimating and managing illegal financial flows do not take into account all income shadowing schemes and channels, and accordingly, do not provide the necessary results.

In addition, taking into account that tax revenues occupy one of the most important components in the structure of filling the state budget, the availability of an effective system of state control over the completeness and timeliness of tax and duties assessment and payment is becoming increasingly important.

Under these conditions, the study of innovative approaches to the estimation of the volume of losses of the economy from the illegal withdrawal of funds, one of which is the assessment of the level of tax gaps in the economy, is of great importance. For today, these approaches have not been adequately researched and developed, especially in the context of foreign economic activity.

Quite often, the very implementation of export-import operations serves as the main mechanism for minimizing tax payments and illegal withdrawal of funds abroad.

The paper proposes an approach to estimating the volume of tax gaps in export-import operations based on the determination of the level of asynchronous export-import activity between partner countries. As a result, it was concluded that there is a direct link between the level of shadowing in the country and the level of asynchrony of foreign economic activity.

On the example of Ukraine, it has been determined that the volume of the tax gap for export-import operations is $0.6 \%$ of the country's GDP, and it is a rather influential factor affecting the level of economic development of the country. The proposed approach may be the basis for further research on the development of a state policy to counteract the shadow economy in the definition of the riskiest in terms of concealing and strengthening the control over the income of partner countries and types of economic activity.

Further studies will be aimed at: estimating the size of the tax gap in the context of certain types of economic activity, which, combined with the results obtained in the framework of this study, will allow expanding the existing tools for counteracting shadow withdrawal through tax channels by identifying the most risky within each partner country activities to increase the control over the activities of the participants in the relevant operations.

Author Contributions: I. K., O. I. - research works of domestic and foreign scientists, devoted to the outline of problems associated with the taxations of export-import operations are investigated; A. F. grouping of countries of the world according to the share of customs payments in the structure of tax revenues is conducted. I. T. - the concept of tax gap is developed; the methodical approaches to the estimation of the tax gaps for export-import operations use by means of the level of asynchronous export-import activity of the country are proposed.

Funding: The survey was funded by the Ministry of Education and Science of Ukraine and performed the results of the project "Econometric modelling of the mechanism of prevention of shadow capital outflows schemes through tax and investment channels in Ukraine" (registration number 0117U003930)

\section{References}

Bekoe, W., Danquah, M., Senahey, S.K. (2016). Tax reform and revenue mobilisation in Ghana. Journal of Economics Studies, 43(4), 522- 534.

Bilan Y., Vasylieva T., Lyeonov S., \& Tiutiunyk I. (2019). Shadow Economy and its Impact on Demand at the Investment Market of the Country. Entrepreneurial Business and Economics Review, Vol. 7, No. 2, 27-43. 
Dakhno, I. I., Albishchenko, N.V., \& Kovalenko, S.V. ta in. (2007). Upravlinnia zovnishnoekonomichnoiu diialnistiu. K Kyiv.: Tsentr uchbovoi literatury

De Boyrie, M., Pak, S., Zdanowicz, J. (2005). Estimating the Magnitude of Capital Flight due to Abnormal Pricing in International Trade: The Russia-USA Case, 29 Accounting Forum, 1-22.

Ebeke, C., Mansour, M., Rota-Graziosi, G. (2016). The Power to Tax in Sub-Saharan Africa: LTUs, VATs, and SARAs. Working Papers, FERDI. P. 254

Fuest, C., Riedel, N. (2010). Tax Evasion and Tax Avoidance in Developing Countries: The Role of International Profit Shifting. Working Papers 1012, Oxford University Centre for Business Taxation.

Grubel, H.G., Lloyd, P.J. (1975). Intra-industry Trade. The Theory and Measurement of International Trade in Differentiated Products. The MacMillan Press Ltd., London.

Harremi, M. (2014). A Simple Analysis of the Tax Gap Balkan Region. Mediterranean Journal of Social Sciences, Vol. 5, No. 19, P. 365.

Illicit Financial Flows Reports (IFFR). Global Financial Integrity official web-site. Retrieved from http://www.gfintegrity.org/reports/

Ipatov, B. G., McClelland, B., \& Cavico F. J. (2018). An Analysis of the Relationship between Regulatory Control and Corruption based on Product and Market Regulation and Corruption Perceptions Indices. Business Ethics and Leadership, 2(3), 6-20.

Khwaja, M. S., lyer, I. (2014). Revenue Potential, Tax Space, and Tax Gap. A Comparative Analysis. Policy Research Working Paper. The World Bank. $41 \mathrm{p}$.

Kostyuchenko, N., Starinskyi, M., Tiutiunyk, I. \& Kobushko, I. (2018). Methodical Approach to the Assessment of Risks Connected With the Legalization of the Proceeds of Crime. Montenegrin Journal of Economics. Vol. 14, No. 4, 23-43.

Krumplyte, J. (2008). Šešelines ekonomikos samprata ir priežasčiu analize. Ekonomika ir vadyba: aktualijos ir perspektyvos, 4(13), 238-250.

McManus, J., Warren, N. (2006). The Case for Measuring Tax Gap. Journal of Tax Research. Retrieved from http://www.austlii.edu.au/au/journals/ eJTR/2006/3.html.

Mitchell, D. (2007). The Tax Gap Mirage. Tax \& Budget Bulletin, Vol. 44. Retrieved from http://www.cato.org/sites/cato.org/files/pubs/pdf/tbb_0306_44.pdf

Murphy, R. (2014). The Tax Gap. Tax Evasion in 2014 - and what can be done about it. London: Public and Commercial Services Union.

Pak, S., Stelios, Z., Zdanowicz, J. (2003). Detecting Abnormal Pricing in International Trade: The Greece-USA Case, Interfaces, 33(2), 54-64.

Report on money laundering methods typology in 2002-2003 (2003). Development group on financial means to combat money laundering. Retrieved from http://www.bank.gov.ua/doccatalog/document?id=36191

Schneider, F. (2015). Size and Development of the Shadow Economy of 31 European and 5 other OECD countries from 2003 to 2015: Different Developments. Retrieved from http://www.econ.jku.at/members/ Schneider/files/publications/2015/ShadEcEurope31.pdf

Schneider, F., Enste, D. (2002) The Shadow Economy: Theoretical Approaches, Empirical Studies, and Political Implications. Cambridge (UK): Cambridge University Press

Teobaldelli, D. and Schneider, F. (2013). The influence of direct democracy on the shadow economy. Public Choice. 157 (3), 543-567.

Toder, E.J. (2007). What Is the Tax Gap?. Tax Notes. Retrieved from http://www.urban.org/UploadedPDF/ 1001112_tax_gap.pdf

Vdovychenko., A. M., Zubrytskyi, A. I., \& Serebrianskyi, D. M. (2013). Tin'ova mizhnarodna torhivlia: makroekonomichna teoriia ta fiskalni naslidky dlia Ukrainy. Kyiv: Alerta.

World Data Bank (2018) Retrieved from http://databank.worldbank.org/data/home.aspx

Zdanowicz, J. S. (2009). Trade-based money laundering and terrorist financing. Review of law \& economics, 5(2), 855-878. 
І.В.Тютюник, к.е.н., доцент, Сумський державний університет (Україна);

I.M. Кобушко, д.е.н., профресор, Сумський державний університет (Україна);

O. Іваній, фінансовий аналітик,спеціаліст зі звітності та інвестиційного контролю, САE Електронік Ltd (Німеччина); сертифікований бухгалтер, Інститут бухаалтерів з менеджменту, Нью-Джерсі (США);

А. Флаумер, Колпінг Академія (Німеччина).

Інновації в управлінні податковими розривами в економіці: зовнішньоекономічна складова

Сучасні світові трансформаційні перетворення відбуваються під впливом екзогенних та ендогенних факторів, які з одного боку виступають стимуляторами даних процесів, а з іншого - поглиблюють дисбаланси в країні. Одним із найбільш впливових фракторів для країн з низьким та середнім рівнем розвитку є тінізація економіки. Саме нелегальні фрінансові операції стримують інвестиційний та інноваційний розвиток країни, знижують темпи ії соціально-економічного розвитку. Побудова ефективної політики нейтралізації та мінімізації впливу даних фракторів можлива лише за умови грунтовного дослідження всіх каналів приховування доходів та визначення обсягу кожного з них. Зважаючи на низьку ефеективність традиційних підходів до управління тінізацією економіки застосування інноваційних методів оцінки, що базуються на визначенні обсягу податкових розривів в економіці може слугувати запорукою підвищення ефективності існуючого інструментарію державного управління в даному напрямі. Ця стаття узагальнює аргументи та контраргументи в межах наукової дискусії щодо оцінки обсягу податкових розривів в економіці в контексті зовнішньоекономічної діяльності країни, як одного із інструментів мінімізації податкових зобов'язань. Систематизація наукових напрацювань з зазначеної проблематики засвідчила, що серед науковців не існує одностайності щодо визначення ролі податкових розривів в економіці та їх взаємозв'язку з зовнішньоекономічною діяльністю країни, що значно актуалізує необхідність подальших емпіричних досліджень у даному напрямку, спрямованих та визначення обсягу податкових розривів в розрізі експортно-імпортної діяльності та їх впливу на показники економічного розвитку країни. Дослідження здійснено на основі використання модифікованої формули Грубеля-Ллойда (що дозволяє визначити індекс асинхронності експортно-імпортної діяльності в ретроспективній динаміці) та показників рівня асинхронності експортної та імпортної діяльності в розрізі країн-партнерів. Об'єктом дослідження є країни, що характеризуються найвищим (Грузія), середнім (Туреччина, Кіпр, Соломонові острови) та найнижчим (Японія, Австрія, США) рівнями тінізації економіки, що дозволяє більш грунтовно та об'єктивно прийняти рішення щодо впливу асинхронності експортно-імпортної діяльності на обсяг податкових розривів в економіці, та його залежність від рівня тінізації в країні за 2013-2017 рр. У роботі представлені результати емпіричного аналізу обсягу податкового розриву за зовнішньоекономічною діяльністю на прикладі України та ї̈ торгівельних партнерів, який показав, що найвищий індекс асинхронності мають країни з середнім рівнем тінізації - Кіпр, Соломонові острови, найнижчий - за участі країн з низьким рівнем тінізації. В той же час, визначено, що один із найвищих індексів асинхронності спостерігається за участі країн-офшорів. Дослідження емпірично підтверджує і теоретично доводить, що зовнішньоекономічна складова займає вагому роль в процесах економічного розвитку країни, а обсяги прихованих податкових платежів, за рахунок даних операцій, займають близько 1\% ВВП країни. Результати досліджень можуть бути корисним для відповідних органів виконавчої влади при розробці заходів щодо запобігання тінізації доходів в розрізі експортно-імпортних операцій.

Ключові слова: асинхронність зовнішньоекономічної діяльності, експортні операції, інновацій підходи до детінізації економіки, операції з імпорту, податкових розрив, тінізація економіки

Manuscript received: 10.07.2019.

(c) The author(s) 2019. This article is published with open access at Sumy State University. 